\title{
Globalization and Post-Secondary Education Policy in Canada:A Review of Trends
}

\author{
Dale Kirby (Memorial University of Newfoundland)
}

\begin{abstract}
In 2005, provincial governments in Ontario and Newfoundland and Labrador each commissioned comprehensive public post-secondary education and training system reviews. While there are considerable differences between the systems and policy approaches in these jurisdictions, the final reports of each of these reviews provide an interesting repository of current post-secondary policy tendencies in Canada. The principal arguments and recommendations put forward in the review reports demonstrate the pervasive influence of economic globalization and the continuing shift to a more utilitarian and market-oriented ideological outlook on post-secondary education's raison d'être. The policies advocated by both reviews illustrate, to varying extents, the impact of dominant influences on modern post-secondary policies including workforce training, privatization, marketization, internationalization and quality assessment mechanisms.
\end{abstract}

\section{Résumé:}

En 2005, les gouvernements provinciaux de l'Ontario et de Terre-Neuve et Labrador ont commandé séparément des comptes-rendus détaillés sur les systèmes publiques d'enseignement et de formation au niveau postsecondaire. Quoiqu'il y ait bien des différences entre les systèmes et les approches politiques des deux provinces, chacun des comptes-rendus finals devient un répertoire intéressant des tendances en cours de la politique de l'éducation post-secondaire. Les recommendations et arguments principaux présentés dans ces comptes-rendus démontrent l'influence envahissante de la mondialisation économique et le changement continu vers une perspective idéologique plus utilitaire et plus orientée vers la commercialisation sur la raison d'être de l'enseignement post-secondaire. Les recommandations de ces deux comptes-rendus démontrent l'effet des influences dominantes sur la politique de l'éducation post-secondaire moderne pour y incorporer la formation de la main-d'œuvre; la privatisation et la commercialisation et les mécanismes d'évaluation de la qualité..

In June 2004, freshman governments in the provinces of Ontario and Newfoundland and Labrador each initiated wide-ranging reviews of their respective post-secondary education and training systems in fulfillment of election platform commitments. The Ontario government had announced its plan for a 
'post-secondary review' on the occasion of the 2004 Budget, their first. In Newfoundland and Labrador, the newly-elected government included their intention to commission a 'white paper' on post-secondary education in its 2004 Speech from the Throne. The mandate of the Ontario review (Ontario, 2005) was two-fold: to provide recommendations on both the structure of the Ontario system and on the model for funding it. Somewhat broader, Newfoundland and Labrador's review (Newfoundland and Labrador, 2005) was mandated to examine the effectiveness, affordability and accessibility of the public post-secondary education system and to examine the system's successes and potential in attracting investment and opportunities for economic development.

The final reports of these reviews, hereinafter referred to as the Ontario report and the Newfoundland report, have key differences but they also have important similarities. One of the major differences relates to the precise nature of what the reports represent with respect to government policy. Whereas the Ontario report contains an external panel's recommendations for the design and funding direction of Ontario's post-secondary system, the Newfoundland report, a White Paper ${ }^{1}$ report, contains policy directions that have been vetted by government and endorsed as official policy. While there are also some considerable differences in the size and scope of the post-secondary systems in these two very different jurisdictions, the review reports provide an interesting snapshot of current postsecondary policy trends in Canada. For instance, the overarching themes of the reports are very similar. The major themes of the Newfoundland report were excellence, affordability, accessibility, collaboration, sustainability and accountability while the principal themes addressed in the Ontario report included accessibility (including affordability), quality, system design (including collaboration), funding and accountability. Under these broad thematic areas, the principal arguments and recommendations put forth in the reports demonstrate the pervasive influence of economic globalization which is accompanied by an increasingly utilitarian, market-oriented ideological outlook on post-secondary education's raison d'être. The policies advocated in the reports illustrate, to varying extents, the dominant impact of such influences on modern postsecondary policies as workforce training, privatization, marketization, internationalization and quality assessment mechanisms. Before exploring these ideas in some depth, it is useful to review some of the dominant trends in postsecondary policy in these provinces prior to the reviews.

\section{From Funding Cuts to Tuition Freeze}

In October 2003, Ontario and Newfoundland and Labrador held general elections that resulted in a change of government. The post-secondary policy legacies of the outgoing governments were somewhat similar, particularly so if one compares their approaches to institutional operating grants and tuition fees. Between 1990 
and 2002, Ontario government grants to colleges and universities decreased about $14 \%$. During this period, provincial grants to Newfoundland and Labrador's postsecondary system decreased by almost 20\% (Junor \& Usher, 2004). Across Canada, the decade of the 1990's was a period of reduced funding for postsecondary education brought about by decreases in federal funding transfers to the provinces. Throughout the 1990's, reductions in provincial funding to Canadian colleges and universities resulted in inflation-exceeding tuition increases and the elimination of most of non-repayable grant aid available to students. In 1990-91, government grants accounted for $69 \%$ of the total revenue of Canadian universities compared to 55\% in 2000-01. From 1990-91 to 2000-01, average undergraduate tuition fees rose $135.4 \%$, more than six times the rate of inflation, and at the end of the decade student fees accounted for $19 \%$ of the average total revenue of Canadian universities compared to $12 \%$ ten years earlier (Statistics Canada, 2002a; Statistics Canada, 2002b).

Following the pattern observed across the country, net government expenditures on post-secondary education in Newfoundland and Labrador declined throughout the 1990's, with these reductions offset by increases in college and university tuition fees (Newfoundland and Labrador, 1995; 1998). In a move away from this policy, between 1999 and 2003 the provincial government began to put money back into the post-secondary education system after a decade of funding cuts. In 1999, the Newfoundland and Labrador government announced that it would provide increased operating funding to the College of the North Atlantic and Memorial University of Newfoundland in order to freeze tuition fees (Newfoundland and Labrador, 1999a; 2000). Between 2001 and 2003, government subsequently subsidized a 25\% reduction in tuition fees at Memorial University while keeping college fees at 1999-2000 levels (Newfoundland and Labrador, 2000). After its election in October 2003, the new Progressive Conservative government opted to continue to hold the line on tuition fees pending an official review of post-secondary policies (Newfoundland and Labrador, 2004a).

As in Newfoundland and Labrador, Ontario government grants to colleges and universities also declined throughout the 1990's. More than two thirds of this funding reduction was instituted in the second half of the decade by the Progressive Conservatives as part of their "Common Sense Revolution", a neo-conservative platform favouring spending and tax cuts, privatization and deregulation (Mackenzie \& Rosenfeld, 2002). As part of its plan for dealing with the growing provincial budget deficit, the Conservatives initially reduced postsecondary operating grants by $15 \%$. Tuition fees, regulated as part of the provincial funding mechanism, were permitted to rise, in some cases by up to $20 \%$, with a portion of the increases reallocated to institutions' needs-based student aid programs. In 1998, fees for graduate and professional programs were 
deregulated entirely, meaning that tuition levels for these programs would be set by institutions rather than by the province (Council of Ontario Universities, 2000). Consistent with the neo-conservative partiality for privatization, the Ontario Conservatives also advocated a greater role for the private sector in the provision of post-secondary education, eventually enacting legislation that strengthened the role of private institutions in degree-granting (though contrary to some predictions this has not facilitated emergence of the private sector as a significant player in degree-granting in Ontario).

In response to public concern about rising costs, beginning in 2000 Ontario universities and colleges were limited to average annual fee increases of up to $2 \%$ across all programs. This policy remained in place until 2004, when it was discontinued by the newly elected Liberals. Consistent with its election promises, the new government opted to freeze all undergraduate tuition fees for 2 years, pending the government's review of the policy on tuition regulation (Ontario, 2000; 2004b).

\section{Globalization and the Objectives of Post-Secondary Education}

The arguments and strategies included in the Ontario and Newfoundland reports are comparable to post-secondary education and training policy approaches taken by many Canadian provinces as they respond and adapt to increasing global competitiveness. The term globalization is often used to refer to the dominating influence of free market forces as economies around the world become more integrated through trade liberalization, advances in technology and increased labour mobility. Broadly speaking, globalization refers to the social, technological, economic, political, geographical, ideological and cultural changes affecting nations around the world (Dudley, 1998; Rojewski \& Lasonen, 2004). Although globalization is frequently associated with increasing deregulation and nation-states' compliance with corporate and commercial interests (Leys, 2001; Rojewski \& Lasonen, 2004; Slaughter \& Leslie, 1997; Turk, 2000), globalization has also been accompanied by increasing levels of state intervention, by recent historical standards, in society and the economy through education, training and labour market policies (Levin, 2003). With the advent of a 'knowledge-based' economy, education is increasingly seen as an agency capable of fostering economic prosperity by facilitating innovation and providing sufficient human capital (i.e., educated workers) to meet the changing demands of industry. This economic-utilitarian policy approach accentuates the contribution of postsecondary education to economic development and places less emphasis on traditional academic-humanist perspectives on post-secondary education, which tend to emphasize education for citizenship and the collective benefit of society. The policy approaches recommended in the reports represent some of the dominant trends in modern post-secondary education including: continuing and 
expanding influence of privatization and marketization in post-secondary systems; growing emphasis on internationalization as a mechanism for meeting national challenges in the areas of workforce development and innovation; and a growing role for government in quantifying and monitoring the quality of post-secondary institutions.

The importance of education as a domestic economic investment, derived from human capital theory, has been articulated by the Organization for Economic Co-operation and Development (OECD). The OECD has observed and reported that increased state investments in human capital by its member countries through post-secondary education has yielded high returns in terms of increased labour market participation, productivity and economic development (OECD, 2003). There is no disputing that post-secondary education has always served both economic and non-economic purposes. The dynamic relationship between the academic-humanist and economic-utilitarian objectives of post-secondary education has been incisively noted by Michael Skolnik (2004):

The economic objectives include preparing people to be productive workers in professional and other occupations and in research which results in new products, new technologies and greater economic efficiency. Important as these objectives are, they stand in contrast to the cultural, moral, civic and broader intellectual purposes of education. Perennial tension exists between these two sets of objectives, and arguably a society is best served when there is a healthy balance between the two. Globalization threatens to upset this balance, as governments employ financial and other policy levers in ways to get universities to forsake academic-humanist objectives in favor of the economic objectives of their activities (Skolnik, 2004, p.4).

Undoubtedly, some sectors within Canadian provincial post-secondary education systems are more utilitarian in their purpose than others. Vocational and workforce training programs are utilitarian by their very character. Institutions in this sector, such as community colleges, are in fact mandated to address the education and skill requirements of industry. There is also a social element to public investment in more vocationally oriented post-secondary institutions: they reduce inequality by providing the public with greater opportunities to access education, opportunities that would not otherwise be realized. In the 1960's Canada's non-university sector grew out of this public demand for access to postsecondary opportunities, and accommodating this desire for access has also served well the nation's workforce requirements (Gallagher \& Dennison, 1995; Schuetze \& Dennison, 2005). With globalization, the economic-utilitarian discourse of workforce education has grown to include university-level studies. Governments have long recognized the connection between universities and economic growth; however, the role of universities in knowledge production, innovation and economic success has become a key public policy focus of the post-industrial 
information age (Fallis, 2005). The potential for universities to supply the highly skilled workers needed to compete internationally is increasingly recognized, and university programs, particularly science, technology, and professional programs, are frequently linked to the preferences of employers and the needs of the 'new economy'.

Government emphasis on the economic-utilitarian objective of postsecondary education is evidenced in the official statements made by the Ontario and Newfoundland and Labrador education ministers when initiating their respective post-secondary reviews. In announcing Newfoundland and Labrador's review, the education minister stated that the post-secondary system needs to be, "well positioned to contribute to the economic growth of our province and the employment prospects of our graduates" (Newfoundland and Labrador, 2004b, para. 3). Ontario's Minister of Training, Colleges and Universities similarly inaugurated the review of Ontario's system by affirming that, "the key to competing and winning in a highly competitive global economy is having the most highly skilled and educated workforce" (Ontario, 2004a, para. 3). As mentioned earlier, the mandate of the Newfoundland and Labrador review included an examination of whether post-secondary institutions were, "achieving their potential to attract investment and support economic development opportunities," in the province (Newfoundland and Labrador, 2005, p.1), while the mandate of the Ontario review similarly linked the post-secondary system's design and funding to government's objective for, "better workers for better jobs in an innovative economy" (Ontario, 2005, p.1). The reports of each of the reviews briefly comment on the benefits of learning at the post-secondary level for the sake of learning itself, and the Ontario report makes this statement outright; however, consistent with their assigned mandates, the observations and recommendations included in the final reports overwhelmingly emphasize economic-utilitarian positions on the purposes of post-secondary study.

Each of the reports emphasizes increasing access to post-secondary education as a means of gaining a competitive advantage, developing a highly skilled workforce and meeting provincial goals for economic growth. The Ontario report notes that, "because the new economy demands it, the number of people attending [post-secondary studies] will need to rise substantially in the years ahead" (Ontario, 2005, p.1). The Newfoundland report similarly observes that, "in a world shaped by information technologies and global economies, post-secondary education offers many opportunities for individuals to participate in community life and achieve economic success" (Newfoundland and Labrador, 2005, p.3). In keeping with this viewpoint, both reports greatly emphasize the need to extend post-secondary access to all who are willing and qualified to attend. Particular attention is devoted to increasing the participation and attainment levels of underrepresented groups, both in the education system and the labour market. Each 
report proposes policy interventions and outreach initiatives intended to increase participation rates for under-represented groups including First Nations peoples, adult learners, francophones, women in "non-traditional fields", students with disabilities, rural populations and "first generation" students - those whose parents did not attend postsecondary education. Again, the increase in access for under-represented groups is tied to economic as well as social objectives.

\section{Privatization of Post-Secondary Education}

In Canada, privatization of post-secondary education does not generally refer to the transfer of public institutions to the private sector. Most often, privatization in the Canadian post-secondary sector refers to the adoption of policies that require individuals to pay a larger portion of the costs for their own education and training, an increasing reliance on private contributions as a source of revenue for post-secondary education and/or creation of privately owned and operated postsecondary institutions. As previously noted, Canadian post-secondary institutions have frequently compensated for decreases in public funding by increasing the required contributions of students through tuition and by intensifying fundraising efforts in order to increase private sector and philanthropic support. Throughout the 1990s, post-secondary institutions in most provinces increased reliance on these funding sources. At present, with over $43 \%$ of post-secondary education revenues coming from private sources, Canada is well above the OECD average of $23 \%$ in terms of private funding for post-secondary education (OECD, 2006).

An occasionally intense policy debate continues to be waged about appropriate levels of tuition fees for Canadian post-secondary institutions. Some student and faculty groups have periodically argued that provincial governments should eliminate tuition fees entirely. It is often pointed out that, in accordance with tuition rationalization theory (Hearn and Longanecker, 1985, p. 489), it is inequitable for all taxpayers to subsidize the total cost of post-secondary education since the majority of college and university students come from middle- and upper-income backgrounds while those from lower socioeconomic backgrounds are vastly under-represented (McGill University, 2007; Stager, 1996). Following this logic, there have been frequent suggestions that it is appropriate for students to for pay some portion of the associated program cost in the form of tuition fees (often 25\%-35\%) because they can expect to incur greater lifetime earnings compared to that of individuals who do not participate in post-secondary education (Concordia University, 2007; Finnie, 2001). Another proposition is that post-secondary education should function under a system where tuition fees are relatively high, compared to current fees, but where available means-tested student financial assistance are equivalently high. It has been suggested that under this "high tuition, high aid" model only slightly fewer students from middle- and upper-income backgrounds would attend, because they are less price-sensitive, 
while college and university participation for students from low-income families would be less encumbered due to the availability of more substantial amounts of financial aid (Hearn \& Longanecker, 1985; Stager, 1996).

Tuition fees were frozen in both Ontario and Newfoundland and Labrador before the provincial post-secondary reviews were undertaken. However, the provincial reports suggest decidedly different approaches to setting tuition fee levels in the two provinces. Newfoundland and Labrador's public postsecondary institutions have the second lowest tuition fees in the country (only Quebec has lower college and university fees). While the Newfoundland report indicated that education is to some degree an individual's private investment and that tuition "represents a relatively small portion of post-secondary education costs and is not a primary contributor to high student debt,"(p. 71), the report recommended a continuation of the fee freeze for a further three-year period. However, despite the fact that the province has the highest incidence and amounts of student borrowing of any province in the country, the report advocated only minor adjustments to existing government student aid programs (e.g., modest increase in weekly borrowing limits) (Junor \& Usher, 2004). In contrast to these recommendations, the Ontario report suggested that the province would be best served by ending its tuition freeze, and by instead developing a new regulatory framework that would assign responsibility for tuition fee levels with institutions. The report asserted that, "the notion that higher education is some kind of nationalized industry, where the price of everything is set by central planners in [government], is out of place in the modern world" (Ontario, 2005, p.23). In tandem with this more deregulated approach to setting tuition fees, the report also recommended significant reforms for Ontario's student-aid programs, with particular attention to the financial needs of students from low and middle-income backgrounds (e.g., up-front grant assistance and increased loan limits).

One key factor associated with post-secondary privatization is notably absent from the provincial post-secondary reviews - private sector deliverers of post-secondary education. Private career colleges, privately owned commercial enterprises, are an important part of post-secondary education in Canada and are governed by provincial legislation in both Ontario and Newfoundland and Labrador. It would have been appropriate to include these institutions in the provincial reviews considering that sizable private vocational training sectors have emerged in most Canadian provinces since the 1980s, encouraged mainly by federal policies on labour-market training and adjustment (McBride \& Kealey, 2000; Schuetze \& Dennison, 2005). Of these institutions, the Ontario postsecondary report states that, "private career colleges also provide valued postsecondary programming. While they are part of the Ontario landscape, they are not part of the mandate of this Review. They are the subject of a separate study by the ministry" (Ontario, 2005, p. 40). This study, a review of the Private 
Career Colleges Act and regulations, was initiated by the Ontario government in March 2004. The Newfoundland review was explicitly mandated to include only those institutions in the public sector and the report makes no reference to the province's private colleges. As in Ontario, the Newfoundland and Labrador government separately reviewed the province's private college legislation and regulations in 1998 (Newfoundland and Labrador, 1999b). By not including private-sector colleges in the provincial reviews, the provincial governments lost an important opportunity to conduct genuinely comprehensive analyses of their post-secondary systems and the appropriate roles and aims of the private

\section{Marketization of Post-Secondary Education}

Post-secondary education privatization is frequently accompanied by marketization. Marketization in post-secondary education is a process whereby traditional academic-humanist values and public and citizenship interests are overtaken or displaced by market principles such as competition, profit, and private-interest. Such market principles place emphasis on more autonomy for education providers and more choice for the education consumer. As Lang (2005) has suggested, public post-secondary institutions in Canada operate in what may be best described as a quasi-market environment; however, market behaviour in the system is increasingly evident. Growing marketization is seen in the restructuring of funding mechanisms away from unconditional operating grant transfers and toward specific, time-limited funding envelopes for program initiatives that meet predetermined government objectives as opposed to that of institutions. These new funding envelopes are often allocated on a competitive basis and sometimes require matching private or partner donations. For example, the federal government has invested several billion dollars in the Canada Foundation for Innovation (CFI), "to strengthen the capacity of Canadian universities, colleges, research hospitals, and non-profit research institutions to carry out world-class research and technology development that benefits Canadians" (CFI, 2007). The CFI funds only a portion of research infrastructure costs with outstanding, matching funds necessarily provided by "partners from the public, private, and voluntary sectors” (CFI, 2007). A basic concern about growing marketization in the post-secondary sector is that some institutions will prosper in a market-based system and some will fare more poorly, for such is the nature of market ideology. In the university community, there are also concerns that the increasing emphasis on the commercial value of research comes at the expense of curiosity-driven research pursuits and impacts the associated tradition of institutional autonomy and academic freedom (Bruneau \& Savage, 2002).

Each of the provincial review reports advocated that institutions continue

to seek private-sector contributions to fund infrastructure and research. The Ontario report observed that the province "must convince the private sector that 
continued investment in research and innovation ... are crucial to the future social and economic health of the province (Ontario, 2005, p. 7)," and that "partner donations have figured prominently in recent capital strategies. They should continue to be encouraged and given priority, but should not be made mandatory" (Ontario, 2005, p. 89). The Newfoundland report proposes a "matching capital fundraising campaign" with government matching privately raised contributions to cover growing infrastructure costs (Newfoundland and Labrador, 2005, p.69). The report characterizes academic research as "a significant economic generator" and "the foundation of the value-added products and services that characterize a knowledge-based economy” (Newfoundland and Labrador, 2005, p.69).

\section{Internationalization of Post-Secondary Education}

Like trends in privatization and marketization, growth in the area of internationalization in post-secondary education has been driven by the forces of globalization. Since the late 1980's, Canadian post-secondary institutions have been responding to demands for an increased international orientation in their outlook. These demands are in response to the growing numbers of students studying abroad, by necessity or choice, and to the advantages of transnational faculty exchange and international collaboration in research. Amongst OECD countries, students from Asia now account for almost half (43\%) of all international students (OECD, 2004). Bohm, Davis, Meares and Pearce (2002) have predicted that Asia will account for more than two-thirds of the coming growth in global demand for post-secondary education - from 1.8 million students in 2000 to 7 million in 2025. The growth in the ease of flow of knowledge across international borders that has been facilitated by advances in information and communications technology has also created new challenges for the traditional methods in Canada's colleges and universities. The Internet-based courses of 'virtual' institutions continue to challenge colleges and universities, particularly those which at one time held near monopolies on post-secondary education in their community or region.

Advancing internationalization in post-secondary education policy can serve a number of academic-humanist objectives. For example, international education can promote mutual understanding, facilitate cultural exchange, and

enhance diversity (Cudmore, 2005). Interest in the furtherance of internationalization is also motivated by economic-utilitarian considerations. In part, interest in internationalization has grown because of the need for colleges and universities to generate revenues from beyond their local and regional domestic student market. Canadian colleges and universities offer post-secondary services to international students without public subsidization on a more or less full-fee basis. Charging far higher tuition fees to these students has provided institutions with an avenue for coping with the decreases in government funding 
over the past two decades. The merits of internationalization in the post-secondary sector are also frequently spoken of in terms of their impact on innovation, international trade, foreign investment, and advancing Canada's overall economic performance (Conference Board of Canada, 1999). The recruitment of talented international students and researchers is one way of responding to the demand for technology and knowledge transfer in the research sectors of developed nations. However, while internationalization can be especially important for economic and workforce development in emerging countries, it can also have less positive consequences in the event that it merely serves to transfer leading talent from Asian and African countries to host countries in the developed world (Cudmore, 2005).

The Ontario and Newfoundland reports emphasize the impact of internationalization in different ways. The Newfoundland report observes that, "new educational models and the search for new markets have led to the breakdown of geographical boundaries and to drastic expansion in the types and missions of educational institutions ... Globally, there is increasing competition to fill jobs with highly-trained and skilled people from many nations" (Newfoundland, 2005, p 15). However, with only one exception, the Newfoundland report does not go into great detail on particular strategies associated with the challenges and benefits of internationalization. The report notes that, as a result of the demographic challenges facing the province, institutions have been compelled to increase their international-student recruitment efforts. International students are of growing importance in light of a projected decline in numbers of potential post-secondary students that will coincide with an overall provincial population decline. In comparison, the Ontario report includes a more extensive discussion of issues associated with internationalization. The report recommends that Ontario more aggressively purse international marketing efforts to promote the province as an important "educational destination" for international students. The primary rationale for this approach is that, "students from other countries who study in Ontario help promote [Ontario's] international reputation, contribute to future trade and economic development opportunities, bring expertise - including high quality researchers and graduate students - to Ontario, and enrich the postsecondary experience for all students” (Ontario, 2005, p. 58). From a less economicutilitarian point of view, the report suggests that Ontario invest in expanded opportunities for student international exchange programs to facilitate, "stronger ties and contacts with the rest of the world and citizens with a better understanding of global issues" (Ontario, 2005, p. 57). 


\section{Quality Assessment in Post-Secondary Education}

As the students and their families have been compelled to cover a greater proportion of the cost for post-secondary education, there has been a coinciding and growing emphasis on institutional accountability and quality. Since the 1980 's, the issue of quality in post-secondary education (its assessment, management and improvement) has become a central policy issue for provincial governments. More and more, post-secondary institutions are required to demonstrate to the general public that they are making efficient use of the funds made available to them and that they are providing high quality output in return these funds. With emergence of a broadening market and adaptation of privatesector management practices in post-secondary education, many jurisdictions have developed systems of performance evaluation to encourage institutional accountability for quality and efficiency. In some instances, systems of performance-based funding have been introduced. The appropriateness and effectiveness of these approaches have been frequently called into question. Depending on how they are designed and implemented, performance indicators and performance funding may in fact reward performance in meeting specific public-policy objectives as opposed to providing some reliable and transparent measure of educational quality (Bruneau \& Savage, 2002; Lang, 2005). Another difficulty with performance indicators is that while such models are easily applied to business production where inputs, processes, and outcomes are much easier to define, quantify and control, the application of these models to the post-secondary sector is limited by the unpredictability and complexity of the post-secondary environment. To begin with, one's perception of quality will depend to some degree on where one's philosophical outlook on post-secondary education lies. While a list of inputs like funding, student and faculty numbers and characteristics, and library holdings, may be readily compiled, agreement on appropriate measures of output has shown itself to be elusive. Outputs may focus on student academic performance (e.g., cumulative averages, graduation/completion rates, number of credits accumulated, average study duration, ratio of graduates to beginners, or numbers of degrees awarded); labourmarket outcomes of students (e.g., graduate employment rates, extent to which students' employment is related to their field of studies, or student performance on professional licensure exams); or satisfaction of education stakeholders (e.g., employers, students, government, social partners). For these reasons, efforts to introduce performance indicators are often met with a combination of skepticism, critique and opposition.

Each of the review reports discusses issues of quality and opposes similar legislated mechanisms for monitoring and evaluating system performance. The processes suggested provide relatively few specifics, leaving much room for subjective judgments of how tangible improvements in quality output are to be 
appropriately defined and demonstrated. The Newfoundland report recommends that the existing Newfoundland and Labrador Council on Higher Education be reconfigured and recognized through legislation. This Council currently operates as a joint initiative of the provincial government and public post-secondary institutions, providing advice on province-wide policy and planning issues and to develop processes for system coordination and articulation. In addition to a Council backed by the force of legislation, the report recommends joint appointments to the boards of Memorial University and College of the North Atlantic to promote collaborative efforts among institutions and achieve efficiencies through cooperation. The report also advises that the province enter into three-year outcomes-based performance contracts with institutions. The report provides the following lengthy list of areas to be included in these performance contracts: "financial performance measurement; efficiencies for shared service delivery; performance reporting on programs; research and administration; an enhanced credit transfer system; enhanced delivery of academic upgrading and other strategies to improve access for under-represented groups; links to economic development from applied research and innovation; and links to regional diversification strategies of the Province" (Newfoundland and Labrador, 2005, p. 77). The ambiguity of this list leaves much open to interpretation. The Ontario report makes frequent reference to the need for colleges and universities to provide quality improvements in exchange for additional funding but specifics are not included. The report suggests that institutions commit to and be held accountable for multi-year plans that establish standards and measures to assess quality. The report recommends that a "Council on Higher Education" be established through legislation to "advise government on how to achieve its learning mission, set targets and measures for improvement, monitor and report on performance and outcomes, co-ordinate research on higher education, and encourage best practices” (Ontario, 2005, p. 30). Again, the report recommends that the development and refinement of a detailed quality assurance framework be assigned to the proposed Council on Higher Education following its creation.

\section{In Summary}

Competition amongst Canadian post-secondary institutions, especially older ones, for students, patrons and prestige, is not a new phenomenon. There is little doubt that this will continue. There has always been some debate about the role of evaluation in post-secondary education, its purpose, definitions, goals and participants. These debates will and should continue. The concept of quality is also not a new one; it is as old as the oldest universities and a necessary concern for those involved at all levels of post-secondary education. Likewise, while postsecondary education is becoming increasingly international, cosmopolitanism has been an age-old feature of the higher education pursuit. The wandering scholar 
has been a participant in university education since ancient times, playing a necessary part in the academic ethos (Kerr, 1990; Pedersen, 1997). This should continue to be so. However, the crucial change addressed in this paper is how economic globalization has altered the outlook on post-secondary education purposes and processes; how it is increasingly seen as an instrument of governments' economic imperatives; and how trends in post-secondary policy are shaped by forces such as privatization and marketization. The two post-secondary reviews discussed leave little doubt that governments have embraced the view that important economic dividends can be derived from public investment in education. There is also an accompanying interest in more influence, by traditional standards, in shaping the directions of post-secondary education through funding, quasi-market mechanisms and legislative authority in questions of quality, accountability and transparency. These are reasonable expectations. But, it is equally reasonable to be attentive to how Canadian post-secondary institutions accommodate the influences of market competition and corporate managerial practices. Considering the pervasive influence of the forces of globalization discussed in this paper, if the current character and diversity of our post-secondary system is to be preserved it is necessary to ensure that the delicate balance between the dual objectives of academic-humanism and economicutilitarianism is preserved.

The extent to which post-secondary education in Canada becomes more economically-oriented and market-driven in still by and large dependent on government regulation and planning. In recent years, Canadian governments have introduced financial, policy and legislative mechanisms that have noticeably increased government involvement in setting the priorities and directions of postsecondary institutions. In both Ontario and Alberta, a portion of provincial funding, albeit a relatively small portion, is contingent on performance in accordance with selected criteria (Eastman, 2003). The recent reviews of postsecondary education in Ontario and Newfoundland and Labrador have advocated greater attention to facilitating quality outcomes. At the same time, governments have also taken measures to open public post-secondary education to private entrepreneurs and investors. In number of provinces, namely Alberta, British Columbia, New Brunswick and Ontario, governments have enacted legislation to permit the operation of private degree-granting institutions, including for-profit institutions, thereby eliminating virtual public-sector monopolies on degreegranting. As the emphasis in Canadian post-secondary continues to shift from academic-humanism toward economic-utilitarianism, one is left to wonder how much of the former will be forgone in accommodating the latter as a means of coping with the forces of globalization, and what will be the long term impact of this exchange on the organization and character of the system? 


\section{Note:}

1. The term White Paper originates from the British government practice of distinguishing shorter unbound position papers from more extensive Blue Books (bound in blue covers) that presented detailed findings and prospective legislation.

\section{References}

Bohn, A., Davis, D., Meares, D., \& Pearce, D. (2002). Global student mobility 2025: Forecasts of the global demand for international higher education. Sydney: IDP Education Australia.

Bruneau, W., \& Savage, D. C. (2002). Counting out the scholars. The case against performance indicators in higher education. Toronto, ON: James Lorimer and Company.

Canada Foundation for Innovation. (2007). CFI overview. Ottawa, ON: Author. Retrieved January 28, 2007, from http://www.innovation.ca/about/index.cfm?websiteid=5 .

Concordia University. (2007, January 23). Presentation by Concordia University to the National Assembly of Québec. Montreal, PQ: Author.

Conference Board of Canada. (1999). The economic implications of international education for Canada and nine comparator countries. Ottawa, Ontario: Author.

Council of Ontario Universities. (2000). Council of Ontario Universities: Briefing notes August 2000. Toronto, ON: Author.

Cudmore, G. (2005). Globalization, internationalization and the recruitment of international students in higher education, and in the Ontario Colleges of Applied Arts and Technology. Canadian Journal of Higher Education, 35(1), 37-60.

Dudley, J. (1998). Globalization and education policy in Australia. In J. Currie and J. Newson (Eds.), Universities and globalization (pp. 21-43). Thousand Oaks: Sage Publications.

Eastman, J. (2003). Strategic management of universities? CSSHE Professional File, Canadian Society for the Study of Higher Education, No. 24, Fall.

Fallis, G. (2005). The mission of the university. CSSHE Professional File, Canadian Society for the Study of Higher Education, No. 26, Summer.

Finnie, R. (2001). Student loans: The empirical record. Canadian Journal of Higher Education, 31(3), 93-142.

Gallagher, P., \& Dennison, J. D. (1995). Canada's community college systems: A study of diversity. Community College Journal of Research and Practice, 12(5), 382-393.

Hearn, J. C., \& Longanecker, D. (1985). Enrollment effects of alternative postsecondary pricing policies. Journal of Higher Education, 56(5), 485-508.

Junor, S., \& Usher, A. (2004). The price of knowledge 2004: Access and student finance in Canada. Montreal, PQ: Canada Millennium Scholarship Foundation.

Kerr, C. (1990) The internationalisation of learning and the nationalisation of the purposes of higher education: Two "laws of motion" in conflict?" European Journal of Education, 25(1), 5-22. 
Lang, D. W. (2005). The political economy of performance funding. In F. Iacobucci and C. Tuohy (Eds.), Taking public universities seriously. Toronto, ON: University of Toronto Press.

Levin, J. S. (2003). Two British Columbia university colleges and the process of economic globalization. Canadian Journal of Higher Education, 33(1), 59-86.

Leys, C. (2001). Market-driven politics: Neoliberal democracy and the public interest. New York: Verso.

Mackenzie, H., \& Rosenfeld, M. (2002). University funding cuts: Shortchanging Ontario students. Ottawa, ON: Canadian Center for Policy Alternatives.

McBride. M., \& Kealey, G. (2000). The impact of privatization on Newfoundland college students: The case of the Career Academy. Toronto, ON: Centre for Research on Work and Society, York University.

McGill University. (2007, January 16). McGill University presentation before the Commission de l'éducation de L'Assemblée nationale du Québec. Montreal, PQ: Author.

Newfoundland and Labrador. (1995). Postsecondary indicators '95. St. John's, NL: Department of Education.

Newfoundland and Labrador. (1998). Post-secondary indicators '98. St. John's, NL: Department of Education.

Newfoundland and Labrador. (1999a). Budget 1999. St. John’s, NL: Queen’s Printer.

Newfoundland and Labrador. (1999b). Review of Private Post-secondary Institutions Act and regulations. St. John's, NL: Department of Education.

Newfoundland and Labrador. (2000). Budget 2000. St. John's, NL: Queen’s Printer.

Newfoundland and Labrador. (2003). Budget 2003. St. John's, NL: Queen's Printers.

Newfoundland and Labrador. (2004a). Budget 2004. St. John’s, NL: Queen's Printers.

Newfoundland and Labrador. (2004b, June 29). Minister launches White Paper on Public Post-Secondary Education.

Newfoundland and Labrador. (2005). Foundation for success: White paper on public postsecondary education. St. John's, NL: Department of Education.

Ontario. (2000, March 14). Government invests in more student spaces, quality programs. Toronto, ON: Ministry of Training, Colleges and Universities.

Ontario. (2004a, June 8). Post-secondary review to improve quality and expand access: Former Premier Bob Rae to conduct comprehensive review. Toronto, ON: Ministry of Training, Colleges and Universities.

Ontario. (2004b, April 8). Tuition freeze a real, positive change for postsecondary students. Toronto, ON: Ministry of Training, Colleges and Universities.

Ontario. (2005). Ontario: A leader in learning. Toronto, ON: Ministry of Training, Colleges and Universities.

Organization for Economic Co-operation and Development. (2003). The sources of economic growth in OECD countries. Paris: Author.

Organization for Economic Co-operation and Development. (2004). Internationalization and trade in higher education: Opportunities and challenges. Paris: Author.

Organization for Economic Co-operation and Development. (2006). Education at a glance 2006. Paris: Author.

Pedersen, O. (1997). The first universities: Studium generale and the origins of university education in Europe. Cambridge: Cambridge University Press.

Rojewski, J. W., \& Lasonen, J. (2004). The role of globalization and context on workforce education and development. In J. W. Rojewski (Ed.), International perspectives on workforce education and development: 
New views for a new century. Greenwich, CT: Information Age Publishing.

Schuetze, H. G., \& Dennison, J. (2005). Extending access, choice and the reign of the market: Higher education reforms in British Columbia. Canadian Journal of Higher Education, 34(3), 13-38.

Skolnik, M. (2004, February). Does structure matter: (Where) do questions about structure fit on the higher education policy agenda? Paper presented at the John Deutsch Institute's Higher Education in Canada Conference, Kingston, Ontario.

Slaughter, S., \& Leslie, L. L. (1997). Academic capitalism: Politics, policies and the entrepreneurial university. Baltimore, MD: Johns Hopkins University Press. (pp. 1-22).

Stager, D.A. (1989). Focus on fees: Alternative policies for university tuition fees. Toronto, ON: Council of Ontario Universities.

Statistics Canada. (2002a, September 16). University finances, 2000/01. The Daily. Ottawa, ON: Ministry of Supply and Services.

Statistics Canada. (2002b, August 21). University tuition fees, 2002/03. The Daily. Ottawa, ON: Ministry of Supply and Services.

Turk, J. L. (Ed.). (2000). The corporate campus: Commercialization and the dangers to Canada's colleges and universities. Toronto: James Lorimer \& Company Ltd.

Dale Kirby is Assistant Professor at the Faculty of Education, G.A. Hickman Building, Memorial University of Newfoundland.

He can be reached at : <dkirby@mun.ca> . 